\title{
Effectiveness, cost effectiveness, acceptability and implementation barriers/ enablers of chronic kidney disease management programs for Indigenous people in Australia, New Zealand and Canada: a systematic review of mixed evidence
}

Rachel Reilly ${ }^{1,2,3^{*}}$, Katharine Evans ${ }^{4}$, Judith Gomersall ${ }^{1,2,6}$, Gillian Gorham ${ }^{4}$, Micah D. J. Peters ${ }^{2}$, Steven Warren ${ }^{5}$, Rebekah O'Shea', Alan Cass ${ }^{4}$ and Alex Brown ${ }^{1}$

\begin{abstract}
Background: Indigenous peoples in Australia, New Zealand and Canada carry a greater burden of chronic kidney disease (CKD) than the general populations in each country, and this burden is predicted to increase. Given the human and economic cost of dialysis, understanding how to better manage CKD at earlier stages of disease progression is an important priority for practitioners and policy-makers. A systematic review of mixed evidence was undertaken to examine the evidence relating to the effectivness, cost-effectiveness and acceptability of chronic kidney disease management programs designed for Indigenous people, as well as barriers and enablers of implementation of such programs.
\end{abstract}

Methods: Published and unpublished studies reporting quantitative and qualitative data on health sector-led management programs and models of care explicitly designed to manage, slow progression or otherwise improve the lives of Indigenous people with CKD published between 2000 and 2014 were considered for inclusion. Data on clinical effectiveness, ability to self-manage, quality of life, acceptability, cost and cost-benefit, barriers and enablers of implementation were of interest. Quantitative data was summarized in narrative and tabular form and qualitative data was synthesized using the Joanna Briggs Institute meta-aggregation approach.

(Continued on next page)

\footnotetext{
*Correspondence: rachel.reilly@sahmri.com

${ }^{1}$ Wardliparingga Aboriginal Research Unit, South Australian Health and

Medical Research Institute, Adelaide, Australia

${ }^{2}$ Johanna Briggs Institute, Faculty of Health Sciences, University of Adelaide,

Adelaide, Australia

Full list of author information is available at the end of the article
} 
(Continued from previous page)

Results: Ten studies were included. Six studies provided evidence of clinical effectiveness of CKD programs designed for Indigenous people, two provided evidence of cost and cost-effectiveness of a CKD program, and two provided qualitative evidence of barriers and enablers of implementation of effective and/or acceptable CKD management programs. Common features of effective and acceptable programs were integration within existing services, nurse-led care, intensive follow-up, provision of culturally-appropriate education, governance structures supporting community ownership, robust clinical systems supporting communication and a central role for Indigenous Health Workers.

Conclusions: Given the human cost of dialysis and the growing population of people living with CKD, there is an urgent need to draw lessons from the available evidence from this and other sources, including studies in the broader population, to better serve this population with programs that address the barriers to receiving high-quality care and improve quality of life.

Keywords: Chronic kidney disease, Indigenous health, systematic review, chronic disease management

\section{Background}

Chronic Kidney Disease (CKD) occurs more frequently and in younger age groups amongst Aboriginal and Torres Strait Islander Australians than non-Indigenous Australians, with rates three to five times the national average in urban areas and up to 30 times the national average in remote areas [1]. Mortality is correspondingly high, with national data indicating CKD is a primary or associated cause of death in $16 \%$ of Indigenous deaths [2]. A disproportionately high burden of CKD has also been found among First Nations people in Canada and Maori people in New Zealand, where there are similar persistent patterns of heath inequities between Indigenous and non-Indigenous people [3-5]. The incidence end-stage kidney disease (ESKD) has almost doubled between 1991 and 2008 and is projected to increase by $130 \%$ from 2009 to $2020[2,6]$. Dialysis is expensive, invasive, and leads to decreased quality of life, particularly for people living in rural and remote locations, who often have to leave their homes for extended periods and/or travel long distances to access treatment [7].

Reducing this burden will require cross-sector primary prevention strategies addressing risk factors across the life course, including increasing access to appropriate health care and early screening, $[1,8]$ as well as improved access to effective and acceptable treatment programs for those with CKD. This review is concerned with programs targeting Indigenous people with established CKD and as such has a deliberate focus on a narrow part of the treatment continuum [9] (Fig. 1). The review was initiated by renal staff working on the 'front line' in primary care settings in central Australia, who expressed an urgent need to find ways of stopping the rapid increase in ESKD, and in particular of understanding what may assist those with early-stage CKD to delay, or prevent, the need for dialysis. The goals of CKD management programs include reducing cardiovascular risk, identifying and managing complications, providing appropriate and timely interdisciplinary health-care, and supporting lifestyle modifications [9-12].

A recent systematic review of CKD programs in the United Kingdom, United States and Canada, found that care provided by a multidisciplinary team, compared to standard medical care, delayed the progression of CKD [13]. The four studies included in this review focused on education as the primary preventative strategy. A comprehensive preliminary search of relevant databases revealed that there is no existing systematic review examining evidence on the effectiveness, cost effectiveness, acceptability and/or implementation barriers/enablers of CKD management programs designed for Indigenous people living in Australia or elsewhere.

The present review sought to address the following questions:

1. What is the effectiveness of CKD programs designed for Indigenous people in relation to outcomes, including, though not limited to: clinical indicators of CKD management such as blood pressure control; the delayed progression of kidney disease/ time to dialysis; and quality of life?

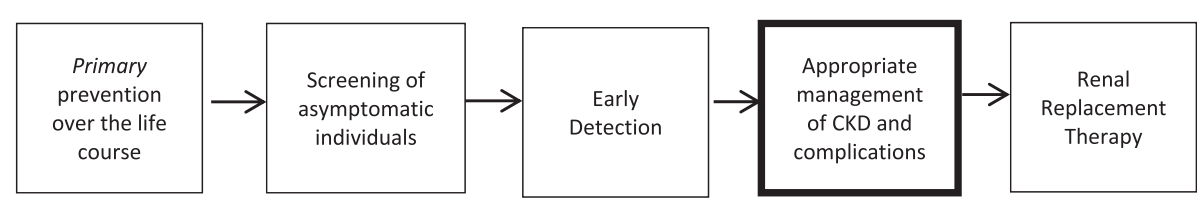

Fig. 1 Focus of this review in relation to the prevention and management pathway for CKD 
2. What are the costs and costs relative to benefits of CKD programs designed for Indigenous people from the perspectives of individual patients and their families, the primary health services that deliver them, tertiary health services and society as a whole?

3. What do patient and provider experiences of CKD programs designed for Indigenous people reveal about the acceptability of programs, as well as barriers and enablers of implementation?

\section{Methods}

A protocol for the review was published in the Joanna Briggs Institute (JBI) Database of Systematic Reviews and Implementation Reports [14]. This project was developed in accordance with the National Health and Medical Research Council's Values and Ethics: Guidelines for ethical research in Aboriginal and Torres Strait Islander Research [15], and with the South Australian Aboriginal Health Research Accord [16].

\section{Search and study selection}

The search strategy sought published and unpublished studies in English, published between 2000 and 2014. Earlier studies were considered less relevant due to advances in technology and data collection. Following the JBI and Cochrane guidelines [17, 18], a four-step search strategy was designed with a view to accessing the most relevant published literature, and also took into account the large amount of Indigenous health research evidence contained in grey literature [19] (Table 1).

The PubMed search strategy is shown in Table 2.

The search results were imported into the EndNote (Thomson Reuters) citation manager and pooled into a single library. After removing duplicates, titles and abstracts were screened against the inclusion criteria by two reviewers ( $R R$ and $K E)$ working independently. Those articles clearly not meeting the inclusion criteria were excluded. The full texts of the remaining articles were examined and those meeting the inclusion criteria were assessed for methodological quality.

\section{Assessment of quality of included studies}

Two reviewers (RR and KE) assessed methodological quality using relevant Joanna Briggs Institute (JBI) standardized critical appraisal instruments [17]. Quantitative papers examining CKD program effectiveness were assessed using the tools contained in the 'JBI Meta-Analysis of Statistics Assessment and Review Instrument' (JBIMAStARI). JBI-MAStARI has separate tools for appraising different study designs. In the absence of a specific tool tailored for appraisal of uncontrolled before and after studies, these were appraised using the 'descriptive/case series' appraisal tool. Studies of costs and cost effectiveness were assessed using the tools contained in the 'JBI Analysis of Cost, Technology and Utilization Assessment and Review Instrument' (JBI-ACTUARI). Qualitative papers were assessed using the tool in the 'JBI Qualitative Assessment and Review Instrument' (JBI-QARI).

Any disagreements that arose between the reviewers were resolved through discussion or with a third reviewer (JG). Studies were classified as good quality if more than $80 \%$ of appraisal characteristics were endorsed, moderate quality if $50-80 \%$ of characteristics were endorsed and poor quality if less than $50 \%$ were endorsed. Those rated as poor quality were excluded.

\section{Data extraction}

Quantitative, economic and qualitative data were extracted from papers included in the review by three reviewers (RR, KE and JG) who worked independently using the standardized data extraction tools from JBI-MAStARI, JBI-ACTUARI and JBI-QARI [17]. Details about study characteristics (e.g., interventions, populations, settings and study methods) were extracted, as well as findings for the outcomes/phenomena of interest relevant to the review. Authors were contacted where necessary to clarify reported data or access information not reported.

\section{Data synthesis}

The findings from included quantitative studies were synthesized using narrative and tables. The findings of qualitative studies were synthesized using the JBI metaaggregation synthesis tool in JBI-QARI. This involved

Table 1 Four-step search strategy

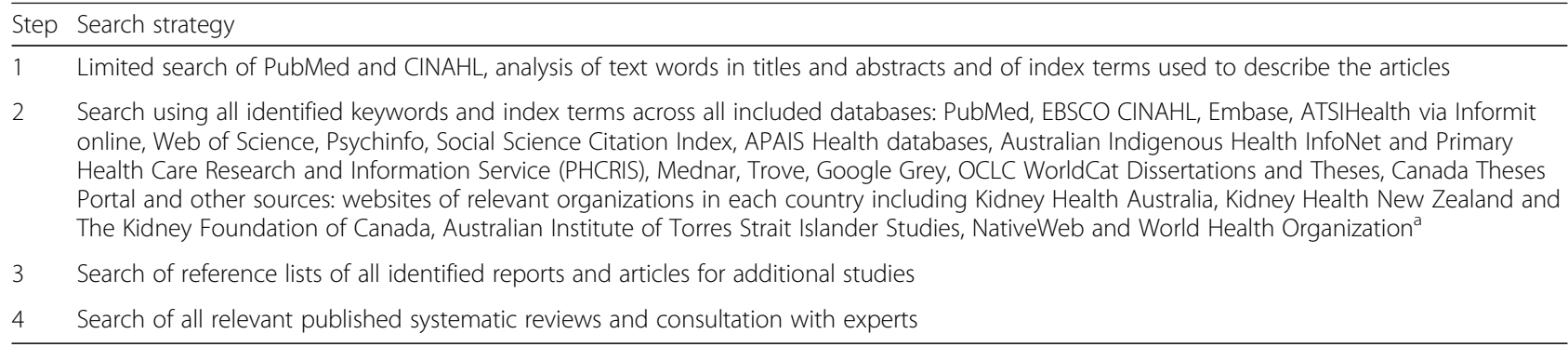

${ }^{a}$ Searches for each database available from the authors 
Table 2 Pubmed search terms

\begin{tabular}{|c|c|}
\hline Search & Query \\
\hline $\begin{array}{l}\text { \#1 Population of } \\
\text { Interest }\end{array}$ & $\begin{array}{l}\text { Australia[mh] OR Australia*[tw] OR.au[ad] OR Australia*[ad] OR Northern Territory[tw] OR Northern Territory[ad] OR Tasmania*[tw] } \\
\text { OR Tasmania*[ad] OR New South Wales[tw] OR New South Wales[ad] OR Victoria*[tw] OR Victoria*[ad] OR Queensland[tw] OR } \\
\text { Queensland[ad] OR Canada[mh] OR Canad*[tw] OR.ca[ad] OR Canad*[ad] OR Alberta[tw] OR Alberta[ad] OR British Columbia[tw] } \\
\text { OR British Columbia[ad] OR Manitoba[tw] OR Manitoba[ad] OR New Brunswick[tw] OR New Brunswick[ad] OR Newfoundland and } \\
\text { Labrador[tw] OR Newfoundland and Labrador[ad] OR Northwest Territories[tw] OR Northwest Territories[ad] OR Nova Scotia[tw] } \\
\text { OR Nova Scotia[ad] OR Nunavut[tw] OR Nunavut[ad] OR Ontario[tw] OR Ontario[ad] OR Prince Edward Illand[tw] OR Prince } \\
\text { Edward Island[ad] OR Quebec[tw] OR Quebec[ad] OR Saskatchewan[tw] OR Saskatchewan[ad] OR Yukon Territory[tw] OR Yukon } \\
\text { Territory[ad] OR New Zealand[mh] OR New Zealand[tw] OR.nz[ad] OR New Zealand[ad] OR Aotearoa[tw]) AND (Oceanic ancestry } \\
\text { group[mh] OR American Native continental ancestry group[mh] OR Maori[tw] OR Aborig*[tw] OR indigenous[tw] OR (Torres } \\
\text { Strait[tw] AND Islander*[tw]) OR Inuit*[tw] OR eskimo*[tw] OR native[tw] OR First Nation*[tw]) }\end{array}$ \\
\hline \#2 Disease & $\begin{array}{l}\text { kidney diseases }[\mathrm{mh}] \mathrm{OR} \text { chronic disease[mh] OR chronic kidney[tw] OR chronic renal[tw] OR predialysis[tw] OR pre dialysis[tw] OR } \\
\text { albumin creatinine ratio[tw] OR estimated glomerular filtration rate[tw] OR diabetic nephropath**tw] }\end{array}$ \\
\hline $\begin{array}{l}\text { \#3 Intervention or } \\
\text { Setting }\end{array}$ & 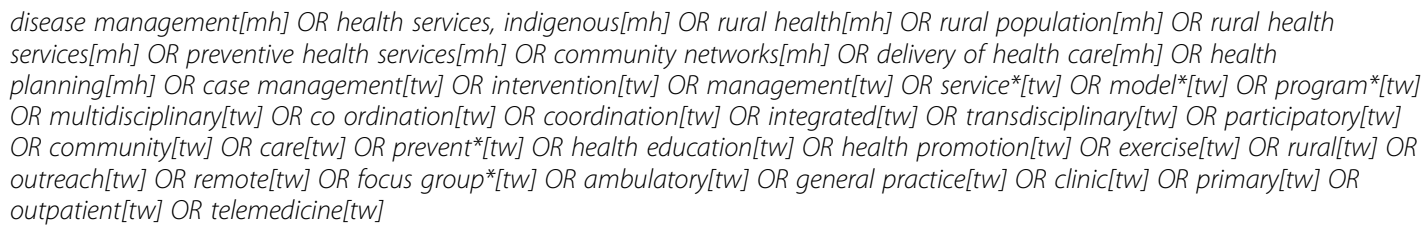 \\
\hline \#4 & $\# 1$ AND \#2 AND \#3 \\
\hline Limits: & Publication date from 01/01/2000-2014; English language. \\
\hline
\end{tabular}

the aggregation of findings to generate a set of representative statements and categorizing the findings on the basis of similarity in meaning. These categories were then subjected to a meta-synthesis to produce a single, comprehensive set of synthesized findings $[17,20]$. The heterogeneity of studies in terms of interventions, populations, reported data and study designs precluded both meta-analysis and second level aggregated synthesis. As such, the results for each question are presented separately below.

\section{Results}

\section{Search and study selection}

As shown in Fig. 2, the search returned 2246 unique citations that were screened by title and abstract against the review inclusion criteria. The full texts of 136 papers were then reviewed independently by the primary and secondary reviewer ( $R R$ and $K E$ ), and reference lists checked for additional relevant articles. Checking the reference lists yielded one additional article that was included for full-text examination. Of these 137 articles, 85 were excluded on the basis of study design, 23 on the basis of population of interest, 2 were conducted in inpatient settings and 12 were duplicates (eg. where there were multiple publications from the same study). Four articles were not accessible after extensive efforts to access electronically and contacting the authors. A list of the studies excluded at full text examination with reasons for exclusion is provided as an additional file. Of the ten included studies, six provided quantitative evidence addressing the question of intervention effectiveness, two on costs (1) and cost effectiveness (1), two provided qualitative evidence on barriers/enablers on CKD program implementation and one study provided quantitative evidence on CKD program acceptability.

\section{Methodological quality of included studies}

The majority of articles were rated as moderate quality, two were good quality and one study of poor quality was excluded [21]. Common weaknesses included a lack of randomisation and insufficient follow-up period for quantitative studies, a lack of clarity around the credibility of values assigned to costs and outcomes for economic studies, and the absence of a statement about the cultural or theoretical position of the researcher, or addressing their influence on the research for qualitative studies. The critical appraisal tools are published in full elsewhere [17] (Table 3).

\section{Findings on the effectiveness of CKD programs Study characteristics}

As outlined in Table 4, of the six studies providing quantitative evidence on program effectiveness, four were conducted in New Zealand [22-25] and two in Australia $[26,27]$. Four of these were uncontrolled prospective cohort designs carried out over one [24, 25] or 2 years $[23,27]$. Of a number of possible publications reporting effectiveness of the Menzies Renal Treatment Program (MRTP), the thesis by Kondalsamy-Chennakesavan [26] was selected because it was the most relevant and comprehensive, including two comparisons: 1) before and after the MRTP was handed over to the Tiwi Health Board (THB); and 2) outcomes from the MRTP versus the THB-run Continuing Care Trial (CCT). Australian participants were younger, on average, than the New 


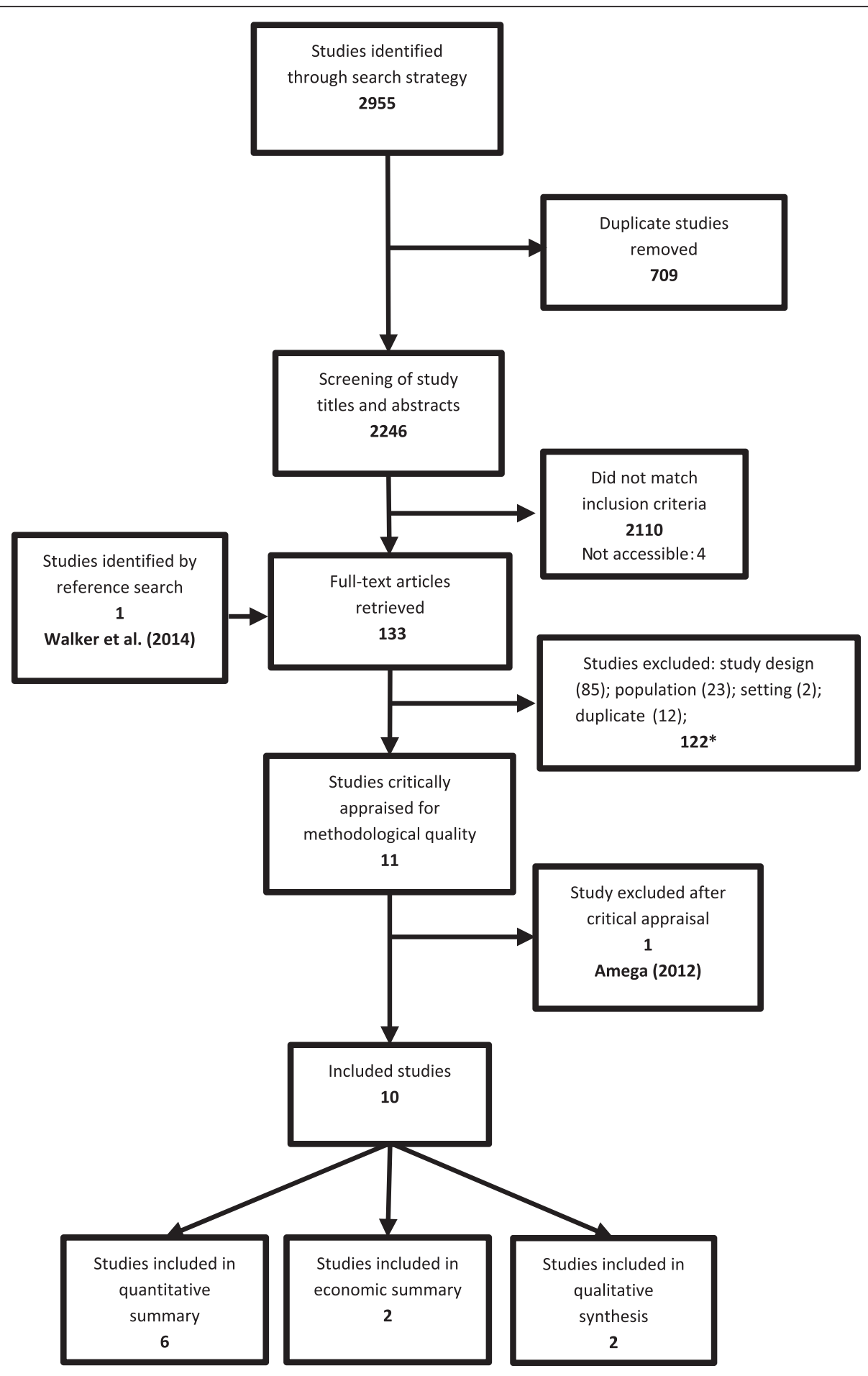

*Full list of excluded articles available from the corresponding author upon request.

Fig. 2 PRISMA Diagram: Search and Study Selection

Zealand participants (weighted averages 44.1 years and 57.8 years respectively). The 437 participants overall were split evenly between men and women (49.9\% men).

\section{Findings}

Studies reported clinical indicators of CKD management including blood pressure control, the use of antihypertensive medication, albumin-creatinine ratio (ACR), 
glycemic index (HbA1c) and glomerular filtration rate. No studies reported data on hard end-points such as dialysis or death. There were also no data reported on quality of life or other psychosocial variables, such as depression or stress.

Relevant clinical outcomes from all studies are shown in Table 5. All intervention groups showed significant reductions in systolic blood pressure from baseline or in relation to comparator groups. All groups who reported on ACR reported reductions, although this was nonsignificant in Shephard [27] This study was limited by very small sample size. Where it was reported, glycated hemoglobin was lower at follow-up for most programs, except for Kondalsamy-Chennakesavan [26], where results were mixed following the handover of the program to the Tiwi Health Board when it was incorporate into routine primary health care. Findings relating to estimated glomerular filtration rate (eGFR) are also mixed.
eGFR is an important indicator of CKD function but is complicated as a measure of program effect because it can decrease in the short term with use of antihypertensive medications. For many people with CKD, GFR reduces steadily over time, while for others it may follow a non-linear trajectory [28].

Indicators of health knowledge and behavior were not widely measured. Hotu et al. [22] measured medication adherence by self-report questionnaire, and found that $80 \%$ took their medication 'most of the time' in the intervention arm, compared to $71 \%$ in usual care. In Shephard et al. [27], tablet counts indicated that $72 \%$ of participants took their medication at least $80 \%$ of the time. Walker et al. [24, 25] measured 'self-management' from the perspectives of patients and clinicians using 13 questions of the Partners in Health instrument [29] and reported improvements in 12 of 13 domains.

Table 3 Critical appraisal of studies meeting the inclusion criteria

\begin{tabular}{|c|c|c|c|c|c|c|c|c|}
\hline & $\mathrm{RCT}$ & $\begin{array}{l}\text { Hotu et } \\
\text { al. (2010) } \\
\text { [22] }\end{array}$ & Comparable Cohort & $\begin{array}{l}\text { Kondalsamy- } \\
\text { Chennakesavan } \\
\text { (2003) [26] }\end{array}$ & Descriptive/Case Series & $\begin{array}{l}\text { Tan et al. } \\
(2014) \\
{[23]}\end{array}$ & $\begin{array}{l}\text { Walker et } \\
\text { al. (2014) } \\
\text { [25] }\end{array}$ & $\begin{array}{l}\text { Walker et } \\
\text { al. (2013) } \\
\text { [24] }\end{array}$ \\
\hline Q1. & $\begin{array}{l}\text { Was the assignment to } \\
\text { treatment groups truly } \\
\text { random? }\end{array}$ & Y & $\begin{array}{l}\text { Is the sample representative } \\
\text { of patients in the population } \\
\text { as a whole? }\end{array}$ & Y & $\begin{array}{l}\text { Was the study based } \\
\text { on a random or pseudo- } \\
\text { random sample? }\end{array}$ & $N$ & $N$ & $N$ \\
\hline Q2. & $\begin{array}{l}\text { Were participants blinded } \\
\text { to treatment? }\end{array}$ & N & $\begin{array}{l}\text { Are the patients at a similar } \\
\text { point in the course of their } \\
\text { condition? }\end{array}$ & $\mathrm{N}$ & $\begin{array}{l}\text { Were the criteria for } \\
\text { inclusion in the sample } \\
\text { clearly defined? }\end{array}$ & Y & Y & Y \\
\hline Q3. & $\begin{array}{l}\text { Was allocation to treatment } \\
\text { groups concealed from the } \\
\text { allocator? }\end{array}$ & Y & $\begin{array}{l}\text { Has bias been minimized in } \\
\text { relation to selection of cases } \\
\text { and controls? }\end{array}$ & U & $\begin{array}{l}\text { Were confounding factors } \\
\text { identified and strategies } \\
\text { to deal with them stated? }\end{array}$ & $N$ & Y & Y \\
\hline Q4. & $\begin{array}{l}\text { Were the outcomes of } \\
\text { people who withdrew } \\
\text { described and included } \\
\text { in the analysis }\end{array}$ & Y & $\begin{array}{l}\text { Are confounding factors } \\
\text { identified and strategies to } \\
\text { deal with them stated? }\end{array}$ & Y & $\begin{array}{l}\text { Were outcomes assessed } \\
\text { using objective criteria? }\end{array}$ & Y & Y & Y \\
\hline Q5 & $\begin{array}{l}\text { Were those assessing } \\
\text { outcomes blind to the } \\
\text { treatment allocation? }\end{array}$ & $\mathrm{N}$ & $\begin{array}{l}\text { Are outcomes assessed using } \\
\text { objective criteria? }\end{array}$ & Y & $\begin{array}{l}\text { If comparisons are being } \\
\text { made, were there sufficient } \\
\text { descriptions of the groups? }\end{array}$ & NA & NA & NA \\
\hline Q6. & $\begin{array}{l}\text { Were the control and } \\
\text { treatment groups } \\
\text { comparable at entry? }\end{array}$ & Y & $\begin{array}{l}\text { Was follow-up carried out } \\
\text { over a sufficient time period? }\end{array}$ & Y & $\begin{array}{l}\text { Was follow-up carried out } \\
\text { over a sufficient time } \\
\text { period? }\end{array}$ & $N$ & $N$ & $N$ \\
\hline Q7. & $\begin{array}{l}\text { Were groups treated } \\
\text { identically other than for } \\
\text { the named interventions? }\end{array}$ & Y & $\begin{array}{l}\text { Were the outcomes of } \\
\text { people who withdrew } \\
\text { described and included in } \\
\text { the analysis? }\end{array}$ & Y & $\begin{array}{l}\text { Were the outcomes of } \\
\text { people who withdrew } \\
\text { included in the analysis? }\end{array}$ & $N$ & Y & Y \\
\hline Q8. & $\begin{array}{l}\text { Were outcomes measured } \\
\text { in the same way for all } \\
\text { groups? }\end{array}$ & Y & $\begin{array}{l}\text { Were outcomes measured in } \\
\text { a reliable way? }\end{array}$ & U & $\begin{array}{l}\text { Were outcomes measured } \\
\text { in a reliable way? }\end{array}$ & Y & Y & Y \\
\hline Q9. & $\begin{array}{l}\text { Were outcomes measured } \\
\text { in a reliable way? }\end{array}$ & Y & $\begin{array}{l}\text { Was appropriate statistical } \\
\text { analysis used? }\end{array}$ & Y & $\begin{array}{l}\text { Was appropriate statistical } \\
\text { analysis used? }\end{array}$ & Y & Y & Y \\
\hline Q10. & $\begin{array}{l}\text { Was appropriate statistical } \\
\text { analysis used? }\end{array}$ & Y & & & & & & \\
\hline \multicolumn{9}{|l|}{ Q11. } \\
\hline & Quality Rating $^{a}$ & $\begin{array}{l}8 / 10 \\
\text { Good }\end{array}$ & & 6/9 Moderate & & $\begin{array}{l}4 / 8 \\
\text { Moderate }\end{array}$ & $\begin{array}{l}6 / 8 \\
\text { Moderate }\end{array}$ & $\begin{array}{l}6 / 8 \\
\text { Moderate }\end{array}$ \\
\hline
\end{tabular}

Y yes, $N$ no, $U$ unclear. ${ }^{a}$ Good: at least $80 \%$; Moderate: $50-80 \%$; Poor: less than $50 \%$ 
Table 3 Critical appraisal of studies meeting the inclusion criteria (Continued)

\begin{tabular}{|c|c|c|c|c|c|c|c|c|}
\hline & $\begin{array}{l}\text { Amega } \\
(2012) \\
{[21]}\end{array}$ & $\begin{array}{l}\text { Shephard et } \\
\text { al. (2006) } \\
\text { [27] }\end{array}$ & Qualitative & $\begin{array}{l}\text { Walker et } \\
\text { al. (2012) } \\
{[34]}\end{array}$ & $\begin{array}{l}\text { Tchan et } \\
\text { al. (2012) } \\
{[33]}\end{array}$ & Economic & $\begin{array}{l}\text { Gador- } \\
\text { Whyte et } \\
\text { al. (2014) } \\
\text { [31] }\end{array}$ & $\begin{array}{l}\text { Baker et } \\
\text { al. (2005) } \\
{[30]}\end{array}$ \\
\hline Q1. & $\mathrm{N}$ & N & $\begin{array}{l}\text { There is congruity between the stated } \\
\text { philosophical perspective and the } \\
\text { research methodology? }\end{array}$ & Y & $U$ & Is there a well-defined question? & Y & Y \\
\hline Q2. & Y & Y & $\begin{array}{l}\text { There is congruity between the } \\
\text { research methodology and the } \\
\text { research question or objectives? }\end{array}$ & Y & Y & $\begin{array}{l}\text { Is there a comprehensive } \\
\text { description of alternatives? }\end{array}$ & NA & NA \\
\hline Q3. & $\mathrm{N}$ & $\mathrm{N}$ & $\begin{array}{l}\text { There is congruity between the } \\
\text { research methodology and the } \\
\text { methods used to collect data? }\end{array}$ & Y & Y & $\begin{array}{l}\text { Are all important and relevant } \\
\text { costs and outcomes for each } \\
\text { alternative identified? }\end{array}$ & Y & $U$ \\
\hline Q4. & Y & Y & $\begin{array}{l}\text { There is congruity between the } \\
\text { research methodology and the } \\
\text { representation and analysis of data? }\end{array}$ & Y & Y & $\begin{array}{l}\text { Has clinical effectiveness been } \\
\text { established? }\end{array}$ & NA & Y \\
\hline Q5 & $\mathrm{N}$ & NA & $\begin{array}{l}\text { There is congruence between the } \\
\text { research methodology and the } \\
\text { interpretation of results? }\end{array}$ & Y & Y & $\begin{array}{l}\text { Are costs and outcomes } \\
\text { measured accurately? }\end{array}$ & Y & Y \\
\hline Q6. & U & N & $\begin{array}{l}\text { There is a statement locating the } \\
\text { researcher culturally or theoretically }\end{array}$ & N & $\mathrm{N}$ & $\begin{array}{l}\text { Are costs and outcomes valued } \\
\text { credibly? }\end{array}$ & Y & $U$ \\
\hline Q7. & $\mathrm{N}$ & Y & $\begin{array}{l}\text { The influence of the researcher on the } \\
\text { research, and vice-versa, is addressed }\end{array}$ & N & $\mathrm{N}$ & $\begin{array}{l}\text { Are costs and outcomes adjusted } \\
\text { for differential timing? }\end{array}$ & $U$ & Y \\
\hline Q8. & U & N & $\begin{array}{l}\text { Participants and their voices are } \\
\text { adequately represented }\end{array}$ & Y & Y & $\begin{array}{l}\text { Is there an incremental analysis of } \\
\text { costs and consequences? }\end{array}$ & $\mathrm{N}$ & Y \\
\hline Q9. & NA & Y & $\begin{array}{l}\text { The research is ethical according to } \\
\text { current criteria or evidence of ethical } \\
\text { approval by an appropriate body }\end{array}$ & Y & Y & $\begin{array}{l}\text { Are sensitivity analyses conducted } \\
\text { to investigate uncertainty in } \\
\text { estimates of cost or } \\
\text { consequences? }\end{array}$ & $\mathrm{N}$ & Y \\
\hline Q10. & & & $\begin{array}{l}\text { Conclusions drawn in the research } \\
\text { report appear to flow from the analysis } \\
\text { or interpretation of the data }\end{array}$ & Y & Y & $\begin{array}{l}\text { Do study results include all issues } \\
\text { of concern to users? }\end{array}$ & $Y$ & $U$ \\
\hline Q11. & & & & & & $\begin{array}{l}\text { Are the results generalizable to } \\
\text { the setting of interest in the } \\
\text { review? }\end{array}$ & U & U \\
\hline & $\begin{array}{l}2 / 8 \\
\text { Poor }\end{array}$ & $\begin{array}{l}4 / 8 \\
\text { Moderate }\end{array}$ & & $\begin{array}{l}8 / 10 \\
\text { Good }\end{array}$ & $\begin{array}{l}7 / 10 \\
\text { Moderate }\end{array}$ & & $\begin{array}{l}5 / 9 \\
\text { Moderate }\end{array}$ & $\begin{array}{l}6 / 10 \\
\text { Moderate }\end{array}$ \\
\hline
\end{tabular}

\section{Findings on the cost and cost effectiveness of CKD programs \\ Study characteristics}

Two studies provided evidence relating to costs or costeffectiveness of CKD programs from the perspective of service providers. Baker et al. [30] measured the costeffectiveness of the Menzies Renal Treatment Program (MRTP), which was also included in the quantitative review [26], and Gador-Whyte et al. [31] compared the estimated the costs of delivering best-practice care, as defined by Central Australian Rural Practitioners' Association (CARPA) guidelines [32], with actual expenditure for patients with Type 2 diabetes and/or CKD in an Aboriginal Community Controlled Health Service in remote Central Australia.

\section{Findings}

When comparing the MRTP to usual care, Baker et al. [30] found that the risk of starting dialysis in the treatment group relative to historical controls over a 4.7 year period was reduced by $57 \%(p=0.03)$, as shown in Table 6 . Moreover, that over the 4.7 years, 36.8 person years of dialysis were avoided by implementing the MRTP. The reduced number of dialysis starts generated net savings of \$4.2 million (in 1997-1998 AUD). Sensitivity analysis indicated that these findings were robust to changes in costing assumptions (Table 7).

Gador-Whyte et al. [31] reported a total funding gap of $\$ 198,728$ per annum or $\$ 1733$ per patient between the projected cost of best practice care and actual expenditure in 2009-2010. No sensitivity analysis was conducted, therefore it is unclear whether funding gaps of similar magnitudes have applied, and continue to exist, in other ACCHS and community settings with different staffing and cost structures. The study also identified workforce shortages, low health literacy and a high acute care workload as factors that may prevent delivery of best practice care (Table 8). 
Table 4 Characteristics of studies addressing question 1

\begin{tabular}{|c|c|c|c|c|c|c|c|}
\hline Study & Objective & Study design & Setting & $\begin{array}{l}\text { Intervention and } \\
\text { comparator }\end{array}$ & Comparator & Participants & $\begin{array}{l}\text { Outcomes } \\
\text { measured }\end{array}$ \\
\hline Tan et al. (2014) [23] & $\begin{array}{l}\text { To determine the } \\
\text { effectiveness of a } \\
\text { PHC-based, nurse-led } \\
\text { CKD program with } \\
\text { Tongan staff can } \\
\text { improve medication } \\
\text { adherence and clinical } \\
\text { outcomes }\end{array}$ & $\begin{array}{l}\text { 2-year prospective } \\
\text { uncontrolled cohort study, } \\
\text { conducted } 2011-2013\end{array}$ & $\begin{array}{l}\text { NZ urban area, } \\
\text { PHC service in } \\
\text { Auckland with } \\
\text { Tongan-speaking } \\
\text { staff }\end{array}$ & $\begin{array}{l}\text { Nurse-led with input } \\
\text { from GP and } \\
\text { diabetologist when } \\
\text { necessary. Focus on } \\
\text { prescribing } \\
\text { antihypertensives and } \\
\text { improving adherence. } \\
\text { BP measured 2-6 } \\
\text { weekly. Some outreach } \\
\text { and lifestyle, dietary and } \\
\text { self-care education. }\end{array}$ & No comparator. & $\begin{array}{l}43 \text { Pasifika patients } \\
\text { with type } 2 \text { diabetes, } \\
\text { CKD (mostly stages } \\
2 \text { and } 3 \text { ) and } \\
\text { hypertension. Mean } \\
\text { age } 53 \text { years, } 77 \% \\
\text { male. } 39 \text { available } \\
\text { for follow-up at } \geq 17 \\
\text { mths. }\end{array}$ & $\begin{array}{l}\text { BP, no. } \\
\text { antihypertensives, } \\
\text { eGFR, ACR, HbA1C }\end{array}$ \\
\hline $\begin{array}{l}\text { Walker et al. (2013, } \\
\text { 2014) }[24,25]\end{array}$ & $\begin{array}{l}\text { To test feasibility and } \\
\text { effectiveness of a } \\
\text { specialist renal nurse-led } \\
\text { self-management } \\
\text { intervention to slow } \\
\text { progression of CKD. }\end{array}$ & $\begin{array}{l}1 \text { year prospective } \\
\text { uncontrolled cohort study, } \\
\text { conducted 2011-2012. }\end{array}$ & $\begin{array}{l}\text { NZ, rural area; two } \\
\text { PHC practices in } \\
\text { Hawke's Bay. }\end{array}$ & $\begin{array}{l}\text { Specialist nurse-led } \\
\text { partnership with primary } \\
\text { care clinicians. Focus on } \\
\text { coaching to improve } \\
\text { self-management. } \\
\text { Individual educational } \\
\text { and clinical care plans } \\
\text { developed followed by } \\
12 \text { weeks of fortnightly } \\
\text { self-management sessions, } \\
\text { with monitoring to } 12 \\
\text { months. Some outreach } \\
\text { and free care, medications } \\
\text { and transport. }\end{array}$ & No comparator. & $\begin{array}{l}52 \text { patients ( } 37 \mathrm{NZ} \\
\text { Māori, } 10 \text { Cook Island } \\
\text { Māori/Samoan and } 5 \\
\text { NZ European) with } \\
\text { type } 2 \text { diabetes, CKD }\end{array}$ & $\begin{array}{l}\text { BP, no. } \\
\text { antihypertensives, } \\
\text { eGFR, ACR, HbA1C, } \\
\text { self-management. }\end{array}$ \\
\hline Hotu et al. (2010) [22] & $\begin{array}{l}\text { To determine whether a } \\
\text { nurse-led community- } \\
\text { based CKD program } \\
\text { involving a Māori or } \\
\text { Pasifika health care } \\
\text { assistant (HCA) ('community } \\
\text { care'; CC) is more clinically } \\
\text { effective than 'usual care' } \\
\text { (UC). }\end{array}$ & $\begin{array}{l}1 \text { year } R C T \text {, conducted } \\
2004-2006 .\end{array}$ & $\begin{array}{l}\text { NZ, urban area; } \\
\text { hospital clinics } \\
\text { and PHC services } \\
\text { in Auckland. }\end{array}$ & $\begin{array}{l}\text { Nurse-led with focus on } \\
\text { prescribing } \\
\text { antihypertensives and } \\
\text { improving adherence. } \\
\text { Monthly outreach by } \\
\text { HCA to monitor BP, } \\
\text { promote adherence and } \\
\text { provide free transport. } \\
\text { Lifestyle, dietary and self- } \\
\text { care education. } \\
\text { Received routine care } \\
\text { as necessary. }\end{array}$ & $\begin{array}{l}\text { Lifestyle, dietary and } \\
\text { self-care education. } \\
\text { Usual care by GP and } \\
\text { renal clinic. }\end{array}$ & $\begin{array}{l}65 \text { Māori and Pasifika } \\
\text { patients with type } 2 \\
\text { diabetes, CKD (mostly } \\
\text { stage 3) and } \\
\text { hypertension (CC: } \\
n=33 ; \text { UC: } n=32 \text { ). } \\
\text { Mean age: CC: 63; UC: } \\
60 \text { years; \% male: CC: } \\
55 \% \text {; UC: } 53 \% \text {. } 58 \\
\text { available for follow-up } \\
\text { at } 12 \text { months (CC: } \\
n=30 \text {; UC: } n=28 \text { ). }\end{array}$ & $\begin{array}{l}\text { BP, no. } \\
\text { antihypertensives, } \\
\text { adherence, eGFR, } \\
\text { ACR, HbA1C. }\end{array}$ \\
\hline $\begin{array}{l}\text { Shephard et al. } \\
\text { (2006) [27] }\end{array}$ & $\begin{array}{l}\text { To determine the clinical } \\
\text { effectiveness (and } \\
\text { acceptability- see below) } \\
\text { of the Umoona Kidney } \\
\text { Project, a PHC-based part } \\
\text { nership between the } \\
\text { local Aboriginal community } \\
\text { controlled health service } \\
\text { (ACCHS) and visiting } \\
\text { specialists from Adelaide. }\end{array}$ & $\begin{array}{l}2 \text { year prospective } \\
\text { uncontrolled cohort study, } \\
\text { conducted 1998-2000. }\end{array}$ & $\begin{array}{l}\text { Australia, remote } \\
\text { area; ACCHS in } \\
\text { Coober Pedy. }\end{array}$ & $\begin{array}{l}\text { Specialist-run with focus } \\
\text { on prescribing } \\
\text { antihypertensives, } \\
\text { delivering ACR point of } \\
\text { care tests (POCT) and } \\
\text { ascertaining acceptability } \\
\text { of project. Regular visits } \\
\text { by nephrologists and } \\
\text { 6-monthly monitoring } \\
\text { of clinical parameters. } \\
\text { Lifestyle and dietary }\end{array}$ & No comparator. & $\begin{array}{l}35 \text { Aboriginal patients } \\
\text { with hypertension } \\
\text { and with or at risk of } \\
\text { CKD ( } 20 \text { had } \\
\text { albuminuria). Mean } \\
\text { age } 49 \text { years, } 54 \% \\
\text { male. Patients } \\
\text { followed for a mean } \\
\text { of } 15 \text { months with } \\
\text { none lost to follow-up. }\end{array}$ & $\begin{array}{l}\text { BP, no. } \\
\text { antihypertensives, } \\
\text { adherence, eGFR, } \\
\text { ACR, program } \\
\text { acceptability. }\end{array}$ \\
\hline
\end{tabular}


Table 4 Characteristics of studies addressing question 1 (Continued)

\begin{tabular}{|c|c|c|c|c|c|c|c|}
\hline $\begin{array}{l}\text { Kondalsamy- } \\
\text { Chennakesavan } \\
\text { (2003) [26] }\end{array}$ & $\begin{array}{l}\text { 1) To determine whether } \\
\text { improvements in BP and } \\
\text { metabolic control were } \\
\text { sustained following the } \\
\text { handover of the visiting } \\
\text { specialist-run MRTP to the } \\
\text { local THB.2) To compare } \\
\text { the effectiveness of the } \\
\text { pre-handover MRTP to } \\
\text { the concurrently run } \\
\text { THB-managed CCT. }\end{array}$ & $\begin{array}{l}2.5 \text { and } 5.5 \text { year retrospective } \\
\text { uncontrolled cohort study, } \\
\text { comparing cohorts:1) } \\
66 \text { month MRTP cohort } \\
(n=101) \text { comparing pre- } \\
\text { handover (1995-1999) and } \\
\text { post-handover (2000-2001).2) } \\
30 \text { month MRTP }(n=149) \\
\text { and CCT ( } n=89 \text { ) cohorts } \\
\text { comparing pre-handover } \\
\text { MRTP to CCT (1997-2000). }\end{array}$ & $\begin{array}{l}\text { Australia, remote } \\
\text { area; ACCHS on } \\
\text { the Tiwi Islands, } \\
80 \mathrm{~km} \text { north of } \\
\text { Darwin. }\end{array}$ & $\begin{array}{l}\text { The MRTP was a specialist- } \\
\text { run project that ran } \\
\text { alongside the local health } \\
\text { care facilities. The focus } \\
\text { was prescribing } \\
\text { antihypertensives. Lifestyle } \\
\text { and dietary education } \\
\text { delivered and individual } \\
\text { treatment plans developed. } \\
\text { Systematic recalls and } \\
\text { active follow-up to } \\
\text { monitor BP. }\end{array}$ & $\begin{array}{l}\text { CCT patients assigned } \\
\text { a chronic disease care } \\
\text { plan and were managed } \\
\text { in routine PHC setting. } \\
\text { No specific resources for } \\
\text { renal patients, opportunistic } \\
\text { follow-up, less systematic } \\
\text { medical oversight. }\end{array}$ & $\begin{array}{l}238 \text { Aboriginal } \\
\text { patients with } \\
\text { hypertension and/or } \\
\text { CKD (mostly stages } 1 \\
\text { and 2). Mean age: } \\
\text { MRTP: 44; CCT: } \\
\text { 42 years; \% male: } \\
\text { MRTP: } 45 \% \text {; CCT: } \\
\text { 44\%. }\end{array}$ & $\mathrm{BP}, \mathrm{HbA} 1 \mathrm{c}$ \\
\hline
\end{tabular}


Table 5 Findings relating to question 1

\begin{tabular}{|c|c|c|c|c|c|c|c|c|c|c|c|c|}
\hline \multirow[b]{2}{*}{$\begin{array}{l}\text { Outcome measure } \\
\text { (n) }\end{array}$} & \multicolumn{2}{|c|}{ Tan et al. (2014) [23] } & \multicolumn{2}{|c|}{ Walker et al. $(2013,2014)[24,25]$} & \multicolumn{2}{|c|}{ Hotu et al. (2010) [22] } & \multicolumn{2}{|c|}{ Shephard et al. (2006) [27] } & \multicolumn{2}{|c|}{$\begin{array}{l}\text { Kondalsamy-Chennakesavan } \\
\text { (2003) [26] \#1 }\end{array}$} & \multicolumn{2}{|c|}{$\begin{array}{l}\text { Kondalsamy-Chennakesavan } \\
\text { (2003) [26] \#2 }\end{array}$} \\
\hline & $\begin{array}{l}\text { Baseline } \\
(n=43)\end{array}$ & $\begin{array}{l}17 \text { mths } \\
(n=39)\end{array}$ & $\begin{array}{l}\text { Baseline } \\
(n=52)\end{array}$ & $\begin{array}{l}12 \mathrm{mths} \\
(n=36)\end{array}$ & $\begin{array}{l}\text { Baseline } \\
C C(n=33) \\
\text { UC }(n=32)\end{array}$ & $\begin{array}{l}12 \mathrm{mths} \\
(n=30) \\
(n=28)\end{array}$ & Baseline & $15 \mathrm{mths}$ & $\begin{array}{l}\text { Baseline } \\
\text { MRTP }(n=149) \\
\text { CCT }(n=89)\end{array}$ & $\begin{array}{l}\text { 30mths } \\
(n=149) \\
(n=89)\end{array}$ & $\overline{\operatorname{Pre}-(n=101)}$ & Post- $(n=101)$ \\
\hline $\begin{array}{l}\text { Systolic Blood Pressure } \\
\mathrm{mmHg(SD)}\end{array}$ & $137(17)$ & $126(16)^{*}$ & $153(15)$ & $131(11)^{*}$ & $\begin{array}{l}161(20) \\
161(20)\end{array}$ & $\begin{array}{l}140(19) \\
149(23)^{* *}\end{array}$ & $151(18)$ & $137(18)^{*}$ & $\begin{array}{l}132(22) \\
126(20)\end{array}$ & $\begin{array}{l}123(16) \\
128(16)^{* *}\end{array}$ & $124(14)$ & $129(15)$ \\
\hline $\begin{array}{l}\text { Median ACR } \\
\mathrm{mg} / \mathrm{mmol}(\mathrm{IQR}) \\
{ }^{\prime} \mathrm{g} / \text { day }(\mathrm{IQR})\end{array}$ & $126(65-194)$ & $51(20-97)$ & $\begin{array}{l}34.9(14.2-150.9) \\
\text { Mean:: } \\
134.5(286.5)\end{array}$ & $\begin{array}{l}\text { Median not } \\
\text { reported } \\
\text { Mean: } \\
44.7(76)^{*}\end{array}$ & $\begin{array}{l}3.3(1.5-3.2) \\
1.6(0.9-4.0)\end{array}$ & $\begin{array}{l}2(0.5-3.8) \\
3.3(1.5-5.3)^{* *}\end{array}$ & $5.7(1.2-15.2)$ & $4.3(1.3-16.7)$ & NA & NA & NA & NA \\
\hline eGFR & $68(50-81)$ & $63.1(42-73)^{*}$ & $63.1(20.2)$ & $60.8(18.2)$ & $\begin{array}{l}39(14) \\
36(15)\end{array}$ & $\begin{array}{l}41(18) \\
33(17)\end{array}$ & 110 & $118^{*}$ & NA & NA & NA & NA \\
\hline $\mathrm{HbA1c} \%(\mathrm{SD})$ & $9.6(24)$ & $8.6(20)^{*}$ & $9.1(14)^{b}$ & $8.0(9)^{b_{*}}$ & $\begin{array}{l}8.3(9)^{\mathrm{a}} \\
8.5(11)^{\mathrm{a}}\end{array}$ & $\begin{array}{l}8.0(10)^{\mathrm{a}} \\
7.9(9)^{\mathrm{a}}\end{array}$ & NA & NA & NA & NA & NA & NA \\
\hline
\end{tabular}

${ }^{*} p<0.05$ from baseline to follow-up

${ }^{* *} p<0.05$ program vs. comparator at follow-up in Hotu et al. (2010) [22]

\#Hotu et al. (2013) measured $24 \mathrm{~h}$ urinary protein

${ }^{\text {a }} \mathrm{SE}$ converted to $\mathrm{SD}(\mathrm{SD}=\mathrm{N} \sqrt{\mathrm{SE}})$

${ }^{\mathrm{b}} \mathrm{Mmol} / \mathrm{mol}$ converted to $\%$

${ }^{c}$ Means provided by author. Change per unit per month $-0.34(-0.55,-0.12), p<0.05$ 
Table 6 Characteristics of studies addressing question 2

\begin{tabular}{|c|c|c|c|c|c|c|c|}
\hline Study & Objective & $\begin{array}{l}\text { Study } \\
\text { design }\end{array}$ & Setting & $\begin{array}{l}\text { Intervention and } \\
\text { comparator }\end{array}$ & Comparator & Participants & Outcomes measured \\
\hline \multirow[t]{3}{*}{$\begin{array}{l}\text { Gador- } \\
\text { Whyte et al. } \\
\text { (2014) [31] } \\
\text { Cost of Best } \\
\text { practice care }\end{array}$} & \multirow{3}{*}{$\begin{array}{l}\text { To estimate, from } \\
\text { a remote ACCHS } \\
\text { perspective, the } \\
\text { cost of completing } \\
\text { best practice chronic } \\
\text { care tasks for patients } \\
\text { with type } 2 \text { diabetes } \\
\text { and/or CKD. }\end{array}$} & \multirow[t]{3}{*}{$\begin{array}{l}\text { Partial } \\
\text { economic } \\
\text { evaluation/ } \\
\text { costing } \\
\text { study. }\end{array}$} & \multirow[t]{3}{*}{$\begin{array}{l}\text { Australia, remote } \\
\text { area; ACCHS in } \\
\text { unnamed Central } \\
\text { Australian } \\
\text { Aboriginal } \\
\text { community. }\end{array}$} & \multirow[t]{3}{*}{$\begin{array}{l}\text { Best practice care } \\
\text { for patients with } \\
\text { diabetes and/or } \\
\text { CKD. }\end{array}$} & \multirow[t]{3}{*}{$\begin{array}{l}\text { Usual care } \\
\text { delivery for } \\
\text { patients with } \\
\text { diabetes and/or } \\
\text { CKD in that } \\
\text { particular } \\
\text { ACCHS setting }\end{array}$} & $\begin{array}{l}\text { Patients: } 205 \\
\text { Aboriginal } \\
\text { patients: } 74 \text { had } \\
\text { diabetes, } 86 \\
\text { had CKD and } \\
45 \text { had both. }\end{array}$ & \multirow{3}{*}{$\begin{array}{l}\text { Costs: annual costs } \\
\text { (total and per patient) } \\
\text { of managing CKD and } \\
\text { diabetes in 2009-2010 } \\
\text { and projected annual } \\
\text { costs using optimal } \\
\text { PHC management; } \\
\text { difference in these } \\
\text { actual and projected } \\
\text { costs. }\end{array}$} \\
\hline & & & & & & $\begin{array}{l}\text { ACCHS staff: } 4 \\
\text { AHWs, } 3 \text { nurses, } \\
1 \text { GP, } 1 \\
\text { educator, } 1 \\
\text { exercise } \\
\text { physiologist. }\end{array}$ & \\
\hline & & & & & & $\begin{array}{l}\text { Conducted } \\
\text { 2010-2011. }\end{array}$ & \\
\hline \multirow[t]{4}{*}{$\begin{array}{l}\text { Baker et al. } \\
\text { (2005) [30] } \\
\text { Menzies } \\
\text { Renal } \\
\text { Treatment } \\
\text { Program }\end{array}$} & \multirow[t]{4}{*}{$\begin{array}{l}\text { To assess, from a } \\
\text { government health } \\
\text { service perspective, } \\
\text { if the MRTP reduced } \\
\text { the costs of treating } \\
\text { ESKD through improved } \\
\text { clinical outcomes. }\end{array}$} & \multirow[t]{4}{*}{$\begin{array}{l}\text { Economic } \\
\text { evaluation. }\end{array}$} & \multirow[t]{4}{*}{$\begin{array}{l}\text { Australia, remote } \\
\text { area; ACCHS on } \\
\text { Tiwi Islands, } \\
80 \text { km north of } \\
\text { Darwin. }\end{array}$} & \multirow[t]{4}{*}{$\begin{array}{l}\text { Program to modify } \\
\text { kidney and } \\
\text { cardiovascular } \\
\text { disease. } \\
\text { Antihypertensives } \\
\text { and health } \\
\text { education offered. }\end{array}$} & \multirow[t]{4}{*}{ Usual Care } & $\begin{array}{l}\text { Intervention } \\
\text { group: } 258 \\
\text { Aboriginal } \\
\text { patients with } \\
\text { hypertension } \\
\text { and/or CKD. }\end{array}$ & $\begin{array}{l}\text { Health outcomes: } \\
\text { Dialysis starts and } \\
\text { dialysis person-years } \\
\text { avoided. }\end{array}$ \\
\hline & & & & & & $\begin{array}{l}\text { Comparator } \\
\text { group: } 229 \\
\text { Aboriginal } \\
\text { patients in a } \\
\text { historical } \\
\text { control group } \\
\text { (1992-1995). }\end{array}$ & $\begin{array}{l}\text { Costs: MRTP delivery } \\
\text { costs; ESKD treatment } \\
\text { costs; total cost. }\end{array}$ \\
\hline & & & & & & \multirow[t]{2}{*}{$\begin{array}{l}\text { Conducted } \\
1995-2000 .\end{array}$} & $\begin{array}{l}\text { Net cost of the } \\
\text { program/savings } \\
\text { compared to } \\
\text { usual care. }\end{array}$ \\
\hline & & & & & & & $\begin{array}{l}\text { Measured at } 3 \text { and } \\
4.7 \text { years. }\end{array}$ \\
\hline
\end{tabular}

Findings on acceptability and barriers/enablers of implementation

\section{Study characteristics}

The two qualitative studies included in the review, from Australia and New Zealand, described experiences of
CKD programs/models of care to Indigenous people from the perspective of providers. Characteristics of included qualitative studies are shown in Table 9. Tchan et al. [33] evaluated the Outback Vascular Health Service (OVHS), described as a chronic disease outreach program. The

Table 7 Comparison of the effects and costs of the MRTP and control at 4.7 years (Baker et al.) [26]

\begin{tabular}{|c|c|c|c|}
\hline & MRTP & Control & Difference \\
\hline Number of client years & 897.8 & 897.8 & \\
\hline Program delivery cost (incremental) & $\$ 987,926$ & $\$ 0$ & $\$ 987,926$ \\
\hline \multicolumn{4}{|l|}{ Endpoint: ESKD treatment } \\
\hline ESKD treatment years incurred & 27.7 & 64.5 & -36.8 \\
\hline ESKD treatment costs incurred & $\$ 3,120,350$ & $\$ 7,265,796$ & $-\$ 4,145,446$ \\
\hline Total cost (program and ESKD costs) & $\$ 4,108,276$ & $\$ 7,265,796$ & $-\$ 3,157,521$ \\
\hline \multicolumn{4}{|l|}{ Endpoint: dialysis start } \\
\hline Relative risk for treatment versus control & \multicolumn{3}{|c|}{$0.43(0.19-0.96), p=0.012$} \\
\hline Reduction in risk of starting dialysis in the treatment versus control & \multicolumn{3}{|c|}{$57 \%, p=0.03$} \\
\hline Number of dialysis starts & 11 & 26 & -15 \\
\hline Lifetime ESKF treatment costs incurred & $\$ 3,853,332$ & $\$ 9,107,875$ & $-\$ 5,254,543$ \\
\hline Total cost (program and lifetime ESKD costs) & $\$ 4,841,258$ & $\$ 9,107,875$ & $-\$ 4,266,618$ \\
\hline
\end{tabular}


Table 8 Costs of usual and best practice care for patients in an ACCHS setting (Gador-Whyte et al.) [27]

\begin{tabular}{lllllll}
\hline & \multicolumn{4}{l}{ Estimated 2009-10 costs $(\$)$} & Projected best practice costs $(\$)$ & Difference $(\$)$ \\
\hline Costs for diabetes and CKD care in a remote ACCHS & Annual & Per patient (mean) & Annual & Per patient (mean) & Annual & Per patient (mean) \\
& 446,585 & 6123 & 645,313 & 7856 & $-198,728$ & -1733
\end{tabular}

study documents service provider experiences of providing care to Aboriginal people with CKD, which reveal barriers and enablers of implementing acceptable and effective CKD care to Aboriginal people. Walker et al. [34] is a descriptive, exploratory study describing pre-dialysis nurses' experiences of delivering care to CKD patients on outpatient clinics. It offers evidence relating to barriers and enablers to providing effective CKD care to Maori and Pasifika patients.

Shephard et al. [27] present the results of a brief survey of program acceptability developed for the Umoona Kidney Program. This 7-item questionnaire was administered to 50 Aboriginal community members, including the participants in the program. Items such as 'Are you happy with the way the kidney team treats you?' were measured on a 5-point scale from 'very much yes' to 'very much no.'

\section{Findings}

Twenty-nine findings on barriers or enablers of CKD program implementation were identified and extracted from the two qualitative studies. Twelve unsupported findings (those without supporting data) in Tchan et al. [33] were excluded. The 17 remaining findings, summarized in Fig. 3, were grouped into four categories. These categories were synthesized into one overall finding. There was no qualitative evidence from the perspectives of patients.

The survey of acceptability reported by Shepard et al. [27] found very positive attitudes amongst community members towards the Umoona Kidney Project. However, the small sample and bias inherent in the phrasing of questions and mode of administration make this questionnaire difficult to interpret with confidence.

\section{Discussion}

The purpose of this review was to examine evidence on the effectiveness, cost effectiveness and acceptability CKD management programs for Indigenous people, as well as barriers and enablers of implementation. Given the broad scope of these questions, which were directed at providing guidance for the design and implementation of future CKD programs, the inclusion criteria were broad and inclusive in regards to the types of programs and outcomes considered. In light of this, the small number of included studies, in particular addressing questions 2 and 3, was surprising. An examination of the studies excluded from this review indicates that there is a lot written but not a lot of it is intervention research. While the heterogeneity, small sample sizes and moderate quality of the included studies limit generalizability, the findings do indicate that targeted CKD programs are effective in improving clinical outcomes for Indigenous people with CKD, such as maintaining blood pressure within target ranges and reducing HbAlc and albuminuria. Alongside data on the effectiveness of programs, the inclusion of evidence on cost, cost-effectiveness, acceptability, and barriers and enablers of implementation was considered important for informing the future program development, given the unique economic, social and cultural contexts in which CKD programs for Indigenous peoples are implemented. The small quantity of

Table 9 Characteristics of studies addressing question 3

\begin{tabular}{|c|c|c|c|c|}
\hline Study & Study design & Setting & Participants & Study objectives \\
\hline $\begin{array}{l}\text { Tchan et al. } \\
\text { (2012) [30] }\end{array}$ & $\begin{array}{l}\text { Mixed methods study. Qualitative } \\
\text { component used a descriptive, } \\
\text { exploratory approach. Semi- } \\
\text { structured interviews and inductive } \\
\text { analysis. Conducted 2009-2012. }\end{array}$ & $\begin{array}{l}\text { Australia, remote } \\
\text { area; ACCHS in } \\
\text { Broken Hill and } \\
\text { surrounding } \\
\text { towns. }\end{array}$ & $\begin{array}{l}20 \text { service providers comprising } 4 \\
\text { medical specialists, } 6 \text { managers, } 2 \\
\text { Aboriginal health workers (AHWs), } \\
5 \text { GPs, } 3 \text { local Aboriginal employees. }\end{array}$ & $\begin{array}{l}\text { To understand provider views } \\
\text { on the implementation of the } \\
\text { Outback Vascular Health Service } \\
\text { (OVHS), a chronic disease } \\
\text { outreach program that operated } \\
\text { regularly within the Maari Ma } \\
\text { ACCHS }\end{array}$ \\
\hline $\begin{array}{l}\text { Walker et al. } \\
\text { (2012) [34] }\end{array}$ & $\begin{array}{l}\text { Descriptive, exploratory approach. } \\
\text { In-depth semi-structured interviews } \\
\text { and thematic analysis guided by } \\
\text { Thomas' (2006) general inductive } \\
\text { approach. }\end{array}$ & $\begin{array}{l}\text { NZ, variety of } \\
\text { areas; pre-dialysis } \\
\text { clinics primarily on } \\
\text { the North Island. }\end{array}$ & $\begin{array}{l}11 \text { pre-dialysis nurses working with } \\
\text { large case-loads of clients approaching } \\
\text { ESKD, including a significant proportion } \\
\text { of Māori and Pasifika patients. }\end{array}$ & $\begin{array}{l}\text { To understand perceptions of } \\
\text { pre-dialysis specialist nurses } \\
\text { on factors influencing their } \\
\text { delivery of effective pre-dialysis } \\
\text { care. }\end{array}$ \\
\hline $\begin{array}{l}\text { Shephard et al. } \\
\text { (2006) [26] }\end{array}$ & $\begin{array}{l}\text { 7-item Cross-sectional survey } \\
\text { measured on a 5-point scale and } \\
\text { administered by either AHWs, } \\
\text { the nurse in charge, community } \\
\text { leaders or a medical student }\end{array}$ & $\begin{array}{l}\text { Australia, remote } \\
\text { area; ACCHS in } \\
\text { Coober Pedy }\end{array}$ & $\begin{array}{l}50 \text { community members including } 27 \\
\text { participants in the Umoona kidney } \\
\text { program }\end{array}$ & $\begin{array}{l}\text { To determine the acceptability } \\
\text { of the Umoona Kidney Project }\end{array}$ \\
\hline
\end{tabular}




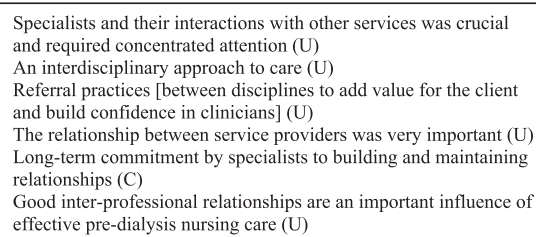

Ownership [by the Aboriginal community] and commitment [by specialists to continue providing a service] (U)

Significant benefits flowed from embedding specialists in the primary care environment [not having to leave your family support network] (U)

\section{$\longrightarrow$}

Good inter-disciplinary and inter-personal relationships enable the implementation of effective and acceptable CKD management programs

Tailoring care to the individual (U)

Day of Clinic- Planning and preparation [contacting patients to ensure they come to clinic] (U)

Follow-up processes at each health service [to get care plan on track and support going forward] (C)

track and support going forward] (C) Having time from referral to commencement of renal replacen therapy to provide adequate education

effective pre-dialysis nursing care. (U)
Having good access to cultural and other supports and an

Having good access to cultural and other supports and an
understanding of differing cultural views of health influences understanding of differing cultural views
effective pre-dialysis nursing care $(U)$

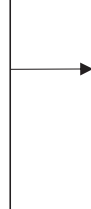

Care tailored to the cultural, social, educational and physical needs of individual clients enables the

implementation of an effective and acceptable CKD management program

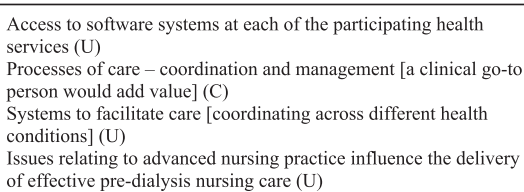

Governance and service structures supporting community ownership and culturally relevant, embedded and accessible care enables the implementation of an acceptable and effective CKD management program

Clinical systems building the capacity and autonomy of nursing and other staff in a multidisciplinary team of nursing and other staff in a multidisciplinary tente implementation of an effective and acceptable CKD management program

Fig. 3 Synthesis of qualitative findings addressing question 3

research addressing these questions suggests that little is currently known about the how CKD management programs for Indigenous peoples are experienced, in particular from the perspectives of clients, their families or communities; and also indicates that economic evaluation is not routinely included in CKD program evaluation. Nonetheless the body of evidence included in the review provides a useful indication of the particular features that should be considered in the design of CKD management programs for Indigenous people.

All programs were multifaceted. While it is not possible to draw conclusions about the particular components of programs that may be causally related to improved outcomes, we identified characteristics common to many of the programs. Future qualitative and quantitative research could explore these questions more fully. Common components of effective programs were: the integration or coordination with primary care; nurse-led or Indigenous Health Worker-led care; intensive follow-up including home-visits; the provision of anti-hypertensive medication following a step-wise protocol; and addressing barriers to adherence such as cost and lack of transport. Education also emerged as a key component of effective programs, but it had to be delivered in ways that accounted for literacy and culture. These program features were consistent with the findings addressing the question of acceptability, and barriers and enablers of implementation. There is also overlap between these findings and evidence in nonIndigenous populations, which indicates that nurse-led and/or multidisciplinary [13, 35], protocol-driven [36] care embedded in primary health care and including patient education tends to lead to better outcomes [13, 35, 36].

To address the question of cost and cost effectiveness (Q2), we sought to identify studies of CKD management programs that considered cost and cost-effectiveness in their evaluations. Such studies involve weighing up factors and conditions specific to a particular time and context. As such, our ability to draw generalizable conclusions from the two included studies is limited. For example, the effectiveness data in Baker et al. [30] should be considered in light of the medical advances that have occurred in routine practice since the data was collected between 1995 and 1998 (although the study was published in 2005). Similarly, Gador-Whyte et al. [31] conducted their study in 2010-2011, and since that time relevant changes to the funding structures of Aboriginal Community Controlled Health Organizations have occurred, such as the introduction of the Practice Incentive Program (PIP) Indigenous Health Incentive, which provides eligible Indigenous health services with a payment for each patient who is registered 
for chronic disease care, and an additional payment for those who receive a target level of care in a calendar year $[37,38]$.

Nonetheless, the studies provide some insights relating to the resourcing of CKD programs. Gador-Whyte et al. [31] provide a valuable outline of what constitutes bestpractice care in a remote Aboriginal Health Service. The funding short-fall between projected (best-practice) and actual expenditure appeared across clinical staff, administrative staff and other operating costs. It was noted that an acute work-load, health literacy, under-staffing and high staff turnover were barriers to the provision of best-practice care, reflecting broader issues such as the challenge of recruiting and retaining staff in remote communities, rather than a funding shortfall per se. Baker et al. [30] suggest that from a government perspective, the Menzies Renal Treatment Program was a 'good buy' for health, as it generated improvement in health outcomes and reduced suffering for patients, as well as monetary savings by reducing dialysis start numbers. The positive impact on quality of life is the stronger and, arguably, sufficient argument for investing in primary and secondary prevention programs. Furthermore, effective management of CKD is likely to have additional benefits for the prevention of other acute and chronic health problems (such as cardiovascular disease), leading to other social and economic benefits that should be taken into account.

Regarding the question of acceptability, and barriers and enablers of implementation (Q3), the two studies included in this review reveal important enablers to implementing CKD management programs to Indigenous people such as governance structures that support community ownership and culturally relevant care; flexible care that can meet the needs of people in their particular context; and robust clinical systems that support communication, staff autonomy and capacity building. In particular, the important role of nurses and Indigenous Health Workers was again highlighted in both studies. These program features are in line with Gibson et al. [39] who found that community engagement, coordination of care, embedding culturally safe care, for example by employing Indigenous people, and respecting patients' perspectives enabled the implementation of chronic disease care. Excluding IHWs from decision-making and poorly performing electronic support systems were barriers to implementation.

\section{Conclusions}

Overall, the findings of this review point to the benefit of CKD care that caters to people in their social and cultural environments. That is, care that is embedded within existing healthcare services that people already use. Health services utilising intensive outreach aim to remove barriers to adhering to medical regimens and attending appointments, as well as enabling education and assisting with goal setting in an appropriate location for individuals and families. The role of nurses and/or Indigenous health workers was emphasised in delivering effective outreach and education, and the role of primary health care services was emphasised, in line with recent policy recommendations [39-41].

There is no doubt that more rigorous evaluations of programs over longer time-frames would assist a better understanding the longer-term effectiveness and sustainability of CKD programs, and to understand the mechanisms by which programs lead to change. Researchers should also be encouraged to adhere to best practice by outlining program theories, to enable the assessment of program fidelity, and a better understanding of why and how a program effect occurs. However, given the human cost of dialysis and the growing population of people living with CKD, there is a critical need to draw lessons from the available evidence, including this and other sources in Australia and internationally, to better serve Indigenous people with programs that address the barriers to receiving high-quality care and improve quality of life.

\begin{abstract}
Abbreviations
ACCHS: Aboriginal community controlled health service; ACR: Albumincreatinine ratio; CKD: chronic kidney disease; eGFR: estimated glomerular filtration rate; ESKD: end-stage kidney disease; HbA1c: Glycated hemoglobin; JBI: Joanna Briggs Institute; JBI-ACTUARI: JBI analysis of cost, technology and utilization assessment and review instrument; JBI-MAStARI: JBI meta-analysis of statistics assessment and review instrument; JBI-QARI: JBI qualitative assessment and review instrument; MRTP: Menzies renal treatment program; SBP: systolic blood pressure; THB: tiwi health board.
\end{abstract}

\section{Competing interests}

The authors declare that they have no competing interests.

\section{Authors' contributions}

$R R, K E, J G, G G, S W$ and $A C$ were involved in the conceptualization of the review. RR collaborated on the design of the review with $K E, J G, G G$ and MP, and developed the review protocol. RR and KE completed the database searches, data extraction, study selection and appraisal with input from JG, GG, AC and AB. RR, KE and JG completed data synthesis. RR drafted the manuscript and all authors provided critical input and approved the final version.

\section{Acknowledgements}

AB is supported by The Sylvia and Charles Viertel Senior Medical Research Fellowship. This project was partially funded by the Australian Government Department of Health. JG was supported by National Health and Medical Research Council (NHMRC) Grant No 1061242. The published material is solely the responsibility of the individual authors and does not reflect the views of NHMRC or the Department of Health. Thanks to Dr. Karla Canuto, Assoc. Prof Craig Lockwood and Prof Randall Faull for their constructive feedback on the protocol, to Jeannie Devitt for her helpful contribution to earlier iterations of the qualitative analysis, to Brita Pekarsky for her constructive insights relating to the economic evidence, to Rachael Walker and A/Prof Srinivas Kondalsamy-Chennakesavan for responding to inquiries relating to their work and to Drs. Paul Lawton and Jaqueline Hughes for their renal expertise.

\section{Author details}

${ }^{1}$ Wardliparingga Aboriginal Research Unit, South Australian Health and Medical Research Institute, Adelaide, Australia. ${ }^{2} J$ ohanna Briggs Institute, 
Faculty of Health Sciences, University of Adelaide, Adelaide, Australia. ${ }^{3}$ Onemda VicHealth Koori Health Group, School of Population and Global Heath, the University of Melbourne, Carlton, Victoria, Australia. ${ }^{4}$ Menzies School of Health Research, Darwin, Australia. ${ }^{5}$ Baker IDI Heart and Diabetes Institute, Alice Springs, Australia. ${ }^{6}$ School of Public Health, University of Adelaide, Adelaide, Australia.

\section{Received: 22 November 2015 Accepted: 23 March 2016}

\section{Published online: 06 April 2016}

\section{References}

1. Cass A, Snelling P, Brown A. Preventing chronic disease to close the gap in life expectancy for Indigenous Australians. In: Baur LA, Twigg S, Magnusson RS, editors. A Modern Epidemic: Expert perspectives on obesity and diabetes. Sydney: University of Sydney Press; 2012. p. 122-30.

2. Australian Institute of Health and Welfare. Chronic Disease Hospitalisations in Australia 2000-01 to 2007-08. Canberra: AlHW; 2010.

3. Burrows NR, Narva AS, Geiss LS, Engelgau MM, Acton KJ. End-stage renal disease due to diabetes among southwestern American Indians, 1990-2001. Diabetes Care. 2005;28:1041-4.

4. Naqshbandi M, Harris SB, Esler JG, Antwi-Nsiah F. Global complication rates of type 2 diabetes in indigenous peoples: a comprehensive review. Diabetes Res Clin Prac. 2008;82:1-17.

5. Stewart JH, McCredie MRE, McDonald SP. The incidence of end-stage renal disease in New Zealand Maori and Pacific Island people and in indigenous Australians. Nephol Dial Transplant. 2004;19:678-85.

6. Australian Institute of Health and Welfare. Chronic Kidney Disease in Aboriginal and Torres Strait Islander People 2011. Canberra: Australian Institute of Heatlh and Welfare; 2011.

7. Rix EF, Barclay L, Stirling J, Tong A, Wilson S. 'Beats the alternative but it messes up your life': Aboriginal people's experience of haemodialysis in rural Australia. BMJ open. 2014; 4:doi: 10.1136/bmjopen-2014-005945

8. Australian Institute of Health and Welfare. Contribution of chronic disease to the gap in adult mortality between Aboriginal and Torres Strait Islander Australians and other Australians. Canberra: Australian Institute of Health and Welfare; 2011

9. Levey AS, Coresh J. Chronic kidney disease. Lancet. 2012;379:165-80

10. Kidney Health Australia. Chronic Kidney Disease Management in General Practice: The Australian Kidney Foundation. 2015.

11. Levin A, Hemmelgarn B, Culleton B, Tobe S, McFarlane P, Ruzicka M, et al. Guidelines for the management of chronic kidney disease. Can Med Assoc J. 2008;179:1154-62.

12. Ministry of Health. Managing Chronic Kidney Disease in Primary Care: National Consensus Statement. Wellington: Ministry of Health; 2015.

13. Strand H, Parker D. Effects of multidisciplinary models of care for adult pre-dialysis patients with chronic kidney disease: a systematic review. Int J Evidence-Based Healthcare. 2012;10:53-9.

14. Reilly RE, Evans K, Gomersall J, Gorham G, Warren S, O'Shea R, et al. Effectiveness, cost effectiveness, acceptability and implementation barriers/ facilitators of chronic kidney disease management programs and models of care for Aboriginal and Torres Strait Islander Australians: a mixed methods systematic review protocol. JBI Database of Systematic Review \& Implementation Reports. 2015;13:65-86.

15. National Health and Medical Research Council. Values and Ethics: Guidelines for Ethical Conduct in Aboriginal and Torres Strait Islander Health Research. Canberra: NHMRC; 2003.

16. Unit WAR. The South Australian Aboriginal Health Research Accord. South Australian Health and Medical Research Institute: Adelaide; 2014.

17. Joanna Briggs Institute. Joanna Briggs Institute Reviewers Manual. 2014th ed. Adelaide: Joanna Briggs Institute; 2014.

18. Higgins JPT, Green S. Cochrane handbook for systematic reivews of interventions 5.1.0 [updated March 2011]. London: Cochrane Collaboration; 2011.

19. Gomersall J, Canuto K, Aromataris E, Braunack-Mayer A, Brown A. Systematic Review to inform prevention and management of chronic disease for Indigenous Australians: overview and priorities. Aust NZ J Publ Heal. 2015; Online. doi:10.1111/1753-6405.12476.

20. Munn Z, Tufanaru C, Aromataris E. JBI's Systematic Reviews: Data Extraction and Synthesis. AJN The Am J Nur. 2014;114:49-54.

21. Amega B. The journey may be longer than you think. Chronicle. 2012;24:15-7.

22. Hotu C, Bagg W, Collins J, Harwood L, Whalley G, Doughty R, et al. A community-based model of care improves blood pressure control and delays progression of proteinuria, left ventricular hypertrophy and diastolic dysfunction in Maori and Pacific patients with type 2 diabetes and chronic kidney disease: a randomized controlled trial. Nephrol Dial Transplant. 2010; 25:3260-6.

23. Tan J, McCready F, Collins J, Cundy R, Oketi T, Noovao F. Intensification of blood pressure treatment in Pasifika people with type 2 diabetes and renal disease: a cohort study in primary care. NZ Med J. 2014;127:27-6.

24. Walker $\mathrm{R}$, Marshall M, Polaschek N. Improving self-management in chronic kidney disease: a pilot study. Renal Soc Australasia J. 2013;9:116-25.

25. Walker RC, Marshall MR, Polaschek NR. A prospective clinical trial of specialist renal nursing in the primary care setting to prevent progression of chronic kidney: a quality improvement report. BMC Fam Pract. 2014;15:14.

26. Kondalsamy-Chennakesavan S. Sustaining renal health outcomes following a community-based intervention program. Darwin: Northern Territory University; 2003

27. Shephard MD, Allen GG, Paizis K, Barbara JA, Batterham M, Vanajek A. Results of an Aboriginal community-based renal disease management program incorporating point of care testing for urine albumin:creatinine ratio. Rural Remote Health. 2006;6:591.

28. Li L, Astor BC, Lewis J, Hu B, Appel LJ, Lipkowitz MS, et al. Longitudinal progression trajectory of GFR among patients wiht CKD. Am J Kidney Dis. 2012;59:504-12.

29. Battersby M, Ask A, Reece M, Markwick M, Collins J. The partners in health scale: the development and psychometric properties of a generic assessment scale for chronic condition self-management. Aust J Primary Health. 2003:9:41-52.

30. Baker PR, Hoy WE, Thomas RE. Cost-effectiveness analysis of a kidney and cardiovascular disease treatment program in an Australian Aboriginal population. Advances Chronic Kidney Dis. 2005;12:22-31.

31. Gador-Whyte AP, Wakerman J, Campbell D, Lenthall S, Struber J, Hope A, et al. Cost of best-practice primary care management of chronic disease in a remote Aboriginal community. Med J Aust. 2014;200:663-6.

32. Central Australian Rural Practitioners Association. CARPA Standard Treatment Manual. 6th ed. Alice Springs: Central Australian Rural Practitioners Association; 2014

33. Tchan M, Cass A, Buckland A, Kong M. The Outback Vascular Health Service: Evaluation Report. Sydney: The George Institute for Global Health. 2012

34. Walker R, Abel S, Meyer A. Perceptions of key influences on effective pre-dialysis nursing care. Contemp Nurs. 2012:42:28-35.

35. Hopkins RB, Garg AX, Levin A, Molzahn A, Rigatto C, Singer J, et al. Costeffectiveness analysis of a randomized trial comparing care models for chronic kidney disease. Clin J Am Soc Nephrol. 2011;6:1248-57.

36. Senior PA, MacNair $L$, Jindal K. Delivery of multifactorial interventions by nurse and dietitian teams in a community setting to prevent diabetic complications: a quality-improvement report. Am J Kidney Dis. 2008;51:425-34.

37. Australian Government Department of Health. Flexible Fund Guidelines: Practice Incentives for General Practices Fund. Canberra: Australian Government Department of Health; 2014

38. Couzos S, Thiele D. The new "Indigenous health" incentive payment: issues and challenges. Med J Aust. 2010;192:154-7.

39. Gibson O, Lisy K, Davy C, Aromataris E, Kite E, Lockwood C et al. Enablers and barriers to the implementation of primary health care interventions for Indigenous people with chronic diseases: a systematic review. Implement Sci. 2015; doi: 10.1186/s13012-015-0261-x

40. Hoy WE. Programmes to recognise and manage the prevalence of chronic disease represent a sea change in healthcare for Indigenous Australians. Br Med J. 2013;347:f6127.

41. Kidney Health Australia, Australian and New Zealand Society of Nephrology. Kidney Health for All: A report on policy options for improving Aboriginal and Torres Strait Islander Kidney Health. Canberra: Kidney Health Australia and Australian and New Zealand Society of Nephrology; 2015. 